\title{
PENGARUH SISTEM OLAH TANAH DAN PEMUPUKAN NITROGEN JANGKA PANJANG TERHADAP PERMEABILITAS TANAH PADA PERTANAMAN JAGUNG (Zea mays L.) DI LAHAN POLITEKNIK NEGERI LAMPUNG
}

\section{THE EFFECT OF LONG TERM NITROGEN AND SOIL TILLAGE SYSTEM ON SOIL PERMEABILITY IN CORN (Zea mays L.) PLANTATION IN STATE POLYTECHNIC OF LAMPUNG}

\author{
Kinar Yoshie Putri", Muhajir Utomo, Nur Afni Afrianti, dan Afandi \\ Jurusan Agroteknologi Fakultas Pertanian Universitas Lampung \\ Jalan Prof. Dr. soemantri Brojonegoro No.1 Bandar Lampung 35145 \\ *E-mail: kinaryoshie0@gmail.com
}

\begin{abstract}
This study aims to determine the effect of tillage systems and the effects of long-term nitrogen fertilization and their interactions on soil permeability. This research is a 32-year long-term research conducted in November 2018 to February 2019 in the land of the Lampung State Polytechnic. The research is a factorial experiment (2x3) arranged in a randomized block design (RCBD) with 4 replications. The first factor is nitrogen fertilization with dose of $0 \mathrm{~kg} \mathrm{~N} \mathrm{ha-l}$ (NO) and $200 \mathrm{~kg} \mathrm{~N} \mathrm{ha}^{-1}$ (N2). The second factor is the tillage systems, there are intensive tillage (IT), minimum tillage (MT), and no tillage (NT). Observation variables include soil permeability, soil organic C, bulk density, soil porosity. The results show that the soil permeability class is not affected either by the tillage system, nitrogen fertilization and by interaction between the two treatments. It seems soil permeability class in all treatment combinations fall in to the medium class.
\end{abstract}

Keywords: Nitrogen fertilization, soil permeability, tillage system.

\begin{abstract}
ABSTRAK
Penelitian ini bertujuan untuk mengetahui pengaruh sistem olah tanah dan pengaruh pemupukan nitrogen jangka panjang serta interaksinya terhadap permeabilitas tanah. Penelitian ini merupakan penelitian jangka panjang tahun ke-32 yang dilaksanakan pada bulan November 2018 sampai Februari 2019 di lahan Politeknik Negeri Lampung. Penelitian ini disusun secara faktorial $(2 \times 3)$ dalam rancangan acak kelompok (RAK) dengan 4 ulangan. Faktor pertama adalah dosis pemupukan Nitrogen dengan $0 \mathrm{~kg} \mathrm{~N} \mathrm{ha}^{-1}\left(\mathrm{~N}_{0}\right)$ dan $200 \mathrm{~kg} \mathrm{~N} \mathrm{ha}^{-1}\left(\mathrm{~N}_{2}\right)$. Faktor kedua adalah sistem olah tanah yaitu Olah Tanah Intensif(OTI), Olah Tanah Minimum (OTM), dan Tanpa Olah Tanah (TOT). Variabel pengamatan meliputi Permeabilitas tanah, C-organik tanah, Berat volume tanah (Bulk Density), Porositas Tanah. Hasil penelitian menunjukkan bahwa kelas permeabilitas tanah tidak dipengaruhi oleh sistem olah tanah dan pemupukan nitrogen dan tidak terjadi interaksi antara kedua perlakuan, kelas Permeabilitas tanah pada semua kombinasi perlakuan masuk ke dalam kelas sedang.
\end{abstract}

Kata kunci: Pemupukan nitrogen, permeabilitas tanah, sistem olah tanah. 


\section{PENDAHULUAN}

Permintaan jagung di negara-negara berkembang menjelang tahun 2020 diperkirakan melebihi beras dan terigu. Permintaan jagung dunia diprediksi meningkat dari 558 juta ton pada tahun 1995 menjadi 837 juta ton pada tahun 2020 , sedangkan ratarata produksi jagung nasional pada tahun 2001 baru mencapai 2,8 tha-1 . Hal ini menunjukkan bahwa perlu ditingkatkan produksi jagung untuk memenuhi permintaan (Subandi, 2003).

Pengolahan tanah merupakan suatu kegiatan manipulasi mekanik terhadap tanah untuk menciptakan kondisi tanah yang baik bagi pertumbuhan tanaman, secara garis besar sistem pengolahan tanah dapat dibagi menjadi dua, pengolahan tanah konvensional yaitu olah tanah intensif(OTI) dan pengolahan tanah konservasi, olah tanah konservasi (OTK) ada 2 yaitu: olah tanah minimum (OTM), tanpa olah tanah (TOT), dan olah tanah intensif(OTI). Sistem pengolahan tanah yang berbeda akan mempengaruhi kondisi tanah baik terhadap sifat fisik, kimia maupun biologi tanah.

Menurut Kartasapoetra dan Sutedjo (2010), peningkatan kesuburan tanah dapat dilakukan dengan penambahan pupuk sesuai kebutuhan tanaman. Pemberian pupuk perlu diperhatikan karena pertanaman dan panenan yang terus-menerus tanpa diimbangi dengan pemberian pupuk akan menguras unsur-unsur hara yang tersedia dalam tanah. Pemberian pupuk yang sesuai kebutuhan akan menjaga kesuburan tanah walaupun digunakan sebagai lahan pertanian. Niswati , dkk (1994) menyatakan bahwa kegiatan olah tanah dan pemupukan $\mathrm{N}$ yang berbeda akan mempengaruhi ketersediaan hara N. Pemupukan N yang dilakukan terus-menerus pada musim tanam sebelumnya dengan sistem olah tanah konservasi memiliki kandungan $\mathrm{N}$ tanah yang lebih tinggi dibandingkan dengan olah tanah intensif.

Menurut Rohmat (2009), kegiatan olah tanah akan mempengaruhi permeabilitas dan ruang pori tanah, jika tanah diolah secara intensif akan terjadi pemadatan tanah terlebih lagi jika dilakukan dengan menggunakan alat-alat berat. Pemadatan tanah yang terjadi menyebabkan pertumbuhan akar terhambat dan menghambat pergerakan air di dalam tanah, sehingga kemampuan tanah untuk meloloskan atau melewatkan air rendah. Permeabilitas tanah juga merupakan suatu kesatuan yang meliputi infiltrasi tanah dan bermanfaat sebagai permudahan dalam pengolahan tanah. Tanah dengan permeabilitas tinggi dapat menaikkan laju infiltrasi sehingga menurunkan laju air larian.

Tujuan Penelitan Berdasarkan latar belakang dan masalah yang telah dikemukakan, maka penelitian ini bertujuan untuk : Mengetahui pengaruh sistem olah tanah terhadap permeabilitas tanah pada pertanaman jagung, mengetahui pengaruh pemupukan nitrogen jangka panjang terhadap permebilitas tanah pada pertanaman jagung, mengetahui interaksi antara sistem olah tanah dan pemupukan $\mathrm{N}$ jangka panjang berpengaruh terhadap permeabilitas tanah pada pertanaman jagung.

\section{BAHAN DAN METODE}

Penelitian ini merupakan penelitian jangka panjang tahun ke-31 dilakukan di kebun percobaan 
Politeknik Negeri Lampung yang terletak pada $105^{\circ} 13^{\prime} 45,5^{\prime \prime}-105^{\circ} 13^{\prime} 48,0^{\prime \prime} \mathrm{BT}$ dan $05^{\circ} 21^{\prime} 19,6^{\prime \prime}-$ $05^{\circ} 21^{\prime} 19,7^{\prime}$ ' LS dengan elevasi $122 \mathrm{~m}$ di atas permukaan laut (Utomo, 2012). Tahun ke-30 semua plot OTK diolah kembali. Penelitian ini dilaksanakan pada bulan November 2018 sampai Febuari 2019. Analisis tanah dilakukan di Laboratorium Ilmu Tanah Fakultas Pertanian Universitas Lampung.

Penelitian dilaksanakan menggunakan Rancangan Acak Kelompok (RAK) yang disusun secara faktorial 2 × 3 dengan 4 ulangan. Faktor pertama adalah pemupukan nitrogen jangka panjang yaitu $\mathrm{N}_{0}=$ $0 \mathrm{~kg} \mathrm{~N} \mathrm{ha}^{-1}$, dan $\mathrm{N}_{2}=200 \mathrm{~kg} \mathrm{~N} \mathrm{ha}^{-1}$, dan faktor kedua adalah sistem olah tanah jangka panjang yaitu $\mathrm{T}_{1}=$ Olah Tanah Intensif (OTI), $\mathrm{T}_{2}=$ Olah Tanah Minimum (OTM), $\mathrm{T}_{3}=$ Tanpa Olah Tanah (TOT). Data yang diperoleh dari penelitian ini kemudian diuji homogenitasnya dengan Uji Bartlett dan adifitasnya dengan Uji Tukey. Setelah asumsi terpenuhi, data diolah dengan analisis ragam dan dilanjutkan dengan Uji Beda Nyata Terkecil (BNT) pada taraf $5 \%$.

Pemupukan yang digunakan pada penelitian ini adalah pupuk N (urea), P (SP36), dan K (KCL). Aplikasi pupuk $\mathrm{P}$ dan $\mathrm{K}$ dilakukan pada 1 minggu setelah tanam dengan dosis $100 \mathrm{~kg} \mathrm{SP} 36 \mathrm{ha}^{-1}$ dan 50 $\mathrm{kg} \mathrm{KCl} \mathrm{ha-1.} \mathrm{Pupuk} \mathrm{N} \mathrm{diberikan} \mathrm{dua} \mathrm{kali,} \mathrm{yaitu} \mathrm{satu}$ per tiga dosis pada saat jagung berumur satu minggu setelah tanam dan dua per tiga dosis pada saat jagung memasuki fase vegetatif maksimum yakni delapan minggu setelah tanam. Pemupukan dilakukan dengan cara dilarik di antara barisan tanaman.

Pemeliharaan meliputi penyulaman, penyiangan, serta pengendalian hama dan penyakit. Penyulaman dilakukan pada lubang tanam yang tidak tumbuh benih jagung dan dilaksanakan satu minggu setelah tanam. Penyiangan dilakukan dengan diberikan herbisida dan mencabut, mengoret gulma yang tumbuh di petak percobaan.

Pengambilan sampel dilakukan pada plot dengan perlakuan tanpa olah tanah (T3), olah tanah minimum (T2), dan olah tanah intensif (T1) yang dikombinasikan dengan pupuk $0 \mathrm{~kg} \mathrm{~N} \mathrm{ha}^{-1}$ (N0) dan $200 \mathrm{~kg} \mathrm{~N} \mathrm{ha}^{-1}$ (N2). Pengambilan sampel dilakukan satu kali yaitu saat pemanenan tanaman. Sampel tanah yang telah diambil dikering anginkan dan di analisis di laboratorium fisika tanah, variabel utama dalam penelitian ini adalah permeabilitas, serta variabel pendukung pada penelitian ini adalah C-organik, berat volume tanah (bulk density), dan porositas tanah.

Penetapan Permeabilitas tanah menggunakan metode constant head. Berikut ini tahapan dalam penetapan permeabilitas tanah Afandi (2019) :

1. Jenuhi contoh tanah dengan merendam pada bak perendaman. Ukur tebal contoh tanah (L) dan luas permukaan contoh tanah (A).

2. Pindahkan contoh tanah ke alat permeabilitas, sambungkan sampel tanah dengan bagian atas alat permeabilitas dengan menggunakan karet ban.

3. Alirkan air dari kran, sampai air konstan pada alat permeabilitas $(\mathrm{h})$

4. Lakukan pengukuran dengan cara mengukur jumlah air yang tertampung $\left(Q_{1}\right)$ selama satu jam $(t)$. Pengukuran hari pertama selesai.

5. Pengukuran jumlah air yang tertampung selanjutnya 
dilakukan keesokan harinya $\left(\mathrm{Q}_{2}\right)$ selama 1 jam.

6. Pengukuran juga dilakukan pada hari ke-3 dan ke-4 $\left(\mathrm{Q}_{3}\right.$ dan $\left.\mathrm{Q}_{4}\right)$ dengan lama pengukuran 1 jam.

7. Hasil pengukuran jumlah air yang tertampung di rerata sehingga dihasilkan nilai Q.

Menghitung permeabilitas tanah dengan rumus :

$$
K=\frac{Q}{t} \times \frac{L}{h} \times \frac{1}{A}
$$

Keterangan :

$\mathrm{K}=$ Permeabilitas tanah $(\mathrm{cm} / \mathrm{jam})$

$\mathrm{Q}=$ Rerata jumlah air yang tertampung pada setiap pengukuran (ml)

$\mathrm{t}=$ Waktu pengukuran ( jam)

$\mathrm{L}=$ Tebal contoh tanah $(\mathrm{cm})$

$\mathrm{h}=$ Tinggi permukaan air dari permukaan contoh tanah $(\mathrm{cm})$

$\mathrm{A}=$ Luas permukaan contoh tanah $\left(\mathrm{cm}^{2}\right)$

Hasil perhitungan permeabilitas tanah kemudian dikelaskan berdasarkan Kelas permeabilitas menurut Uhland dan O’Neal (1951) dalam Afandi (2019) pada Tabel 1.

\section{HASIL DAN PEMBAHASAN}

\section{Permeabilitas Tanah}

Permeabilitas tanah merupakan variabel utama yang diamati dalam penelitian ini. Tabel 2 menunjukkan bahwa perlakuan berbagai sistem olah tanah dan pemupukan nitrogen memiliki nilai permeabilitas yang berbeda-beda. Permeabilitas tanah pada penelitian ini berkisar antara 4,85-5,35 $\mathrm{cm} \mathrm{jam}^{-1}$ berdasarkan kelas kecepatan permeabilitas tanah menurut Uhland dan O’neal (1951) dalam Afandi (2019) semua perlakuan tersebut termasuk ke dalam kelas sedang.

Hasil penelitian Rohmah (2018) yang merupakan penelitian sebelumnya (tahun ke-29), menunjukkan bahwa permeabilitas tanah pada penelitian tersebut memiliki nilai rata-rata berkisar 1,16$3,62 \mathrm{~cm} \mathrm{jam}^{-1}$. Dibandingkan dengan penelitian tersebut nilai rata-rata pada penelitian ini mengalami kenaikan. Hal ini diduga oleh adanya pengolahan tanah pada semua plot olah tanah konservasi, sehingga tidak berbeda nyata dengan olah tanah intensif.

Pada sistem olah tanah intensiftidak dilakukan pemanfaatan gulma dan sisa-sisa tanaman dijadikan mulsa dan dilakukan olah tanah minimal dua kali. Pengolahan tanah beberapa kali dapat menyebabkan terbentuknya ruang pori, sehingga ruang pori tanah meningkat dan permeabilitas tanah pun dapat meningkat.

Pada sistem olah tanah minimum dan tanpa olah tanah, dilakukan pemanfaatan gulma dan sisa-sisa tanaman dijadikan mulsa yang berfungsi sebagai penutup tanah atau pelindung tanah dari butir-butir hujan yang jatuh ke tanah. Akibat pemanfaatan gulma dan sisa-sisa tanaman yang dijadikan sebagai mulsa maka, kadar bahan organik menjadi tinggi. Ketersediaan bahan organik juga sangat mempengaruhi aktivitas biota tanah pada permukaan tanah sehingga cenderung menurunkan berat volume tanah dan akan meningkatkan ruang pori total tanah. Bahan organik tanah membantu dalam pembentukan agregat tanah melalui proses pembesaran volume dan peningkatan pori-pori tanah yang ada, sehingga ruang pori total tanah meningkat danmeningkatkan permeabilitas tanah (Ardiansyah, 2015). 
Tabel 1. Kelas permeabilitas menurut Uhland dan O’Neal (1951) dalam Afandi (2019).

\begin{tabular}{cc}
\hline Kelas Permeabilitas Tanah & Permeabilitas Tanah $\left(\mathrm{cm} \mathrm{jam}^{-1}\right)$ \\
\hline Sangat Cepat & $>25$ \\
Cepat & $12,5-25$ \\
Agak Cepat & $6,25-12,5$ \\
Sedang & $2,00-6,25$ \\
Agak Lambat & $0,5-2,00$ \\
Lambat & $0,125-0,5$ \\
Sangat Lambat & $<0,125$ \\
\hline
\end{tabular}

Tabel 2. Kelas permeabilitas tanah beberapa kombinasi sistem olah tanah dan pemupukan N.

\begin{tabular}{ccc}
\hline Perlakuan & $\begin{array}{r}\text { Permeabilitas Tanah } \\
\left(\mathrm{cm} \mathrm{jam}^{-1}\right)\end{array}$ & Kelas Permeabilitas * $)$ \\
\hline N0T1 & 5,15 & Sedang \\
N0T2 & 4,86 & Sedang \\
N0T3 & 4,85 & Sedang \\
N2T1 & 5,24 & Sedang \\
N2T2 & 4,92 & Sedang \\
N2T3 & 5,35 & Sedang \\
\hline
\end{tabular}

Keterangan *=Kelas permeabilitas tanah menurut Uhland dan O'neal (1951) dalam Afandi (2019)

\section{C-Organik Tanah}

Karbon Organik tanah merupakan salah satu faktor penting yang mempengaruhi permeabilitas tanah. Berdasarkan uji BNT taraf $5 \%$ pada Tabel 3 menunjukkan bahwa perlakuan sistem olah tanah dan pemupukan nitrogen jangka panjang memberikan pengaruh yang nyata pada kandungan karbon organik tanah. Sistem olah tanah intensifmemiliki kandungan karbon organik tanah terendah yaitu sebesar 1,53\% dan berbeda nyata dengan sistem olah tanah yang lainnya.

Rendahnya kandungan karbon organik pada sistem olah tanah intensif disebabkan gulma dan residu tanaman pada olah tanah intensif dibuang atau disingkirkan dari lahan pertanaman, sehingga lahan tidak mendapat tambahan sumber bahan organik.
Selain itu, pengolahan tanah secara intensif akan mempercepat proses dekomposisi bahan organik yang akhirnya dapat menyebabkan penurunan bahan organik tanah (Rachman dkk., 2015).

Sistem olah tanah minimum dan tanpa olah tanah memiliki kandungan bahan organik yang tinggi yaitu sebesar 1,68\% dan 1,66\% sementara sistem olah tanah intensif hanya sebesar 1,53\%. Hal ini disebabkan pada olah tanah minimum dan tanpa olah tanah gulma dan residu tanaman sebelumnya dikembalikan pada lahan pertanaman, sehingga menjadi sumber bahan organik tanah. Sistem olah tanah minimum merupakan sistem pengolahan tanah dengan pengolahan seperlunya saja, dan pada sistem tanpa olah tanah lahan tidak diolah sama sekali. Gulma dapat 
Tabel 3. Pengaruh sistem olah tanah dan pemupukan N terhadap Karbon Organik Tanah.

\begin{tabular}{ccc}
\hline & Perlakuan & Karbon Organik Tanah (\%) \\
\hline \multirow{3}{*}{ Sistem olah tanah } & Olah Tanah Intensif & $1,53 \mathrm{~b}$ \\
& Olah Tanah Minimum & $1,68 \mathrm{a}$ \\
& Tanpa Olah Tanah & $1,66 \mathrm{a}$ \\
\hline BNT 5\% & $0 \mathrm{~kg} \mathrm{~N} \mathrm{ha}^{-1}$ & 0,12 \\
\hline \multirow{2}{*}{ Pemupukan Nitrogen } & $200 \mathrm{~kg} \mathrm{~N} \mathrm{ha}^{-1}$ & $1,69 \mathrm{a}$ \\
& & $1,55 \mathrm{~b}$ \\
\hline BNT 5\% & & 0,10 \\
\hline
\end{tabular}

Keterangan : Nilai tengah pada kolom yang diikuti huruf yang sama tidak berbeda nyata menurut uji BNT pada taraf $5 \%$.

Tabel 4. Berat volume tanah, porositas tanah, dan volume pori total akibat penerapan berbagai sistem olah tanah dan pemupukan nitrogen.

\begin{tabular}{ccccc}
\hline Perlakuan & $\begin{array}{c}\text { Berat Volume Tanah } \\
\left(\mathrm{g} \mathrm{cm}^{-3}\right)\end{array}$ & Berat Jenis Tanah & Porositas (\%) & $\begin{array}{c}\text { Persen Volume } \\
\text { Pori Total (\%) }\end{array}$ \\
\hline N0T1 & 1,02 & 2,41 & 57,73 & 57,25 \\
N0T2 & 1,02 & 2,43 & 59,30 & 59,00 \\
N0T3 & 0,99 & 2,44 & 57,71 & 57,00 \\
N2T1 & 1,02 & 2,41 & 57,68 & 57,25 \\
N2T2 & 1,03 & 2,38 & 57,06 & 57,50 \\
N2T3 & 1,00 & 2,35 & 57,53 & 56,50 \\
\hline
\end{tabular}

Keterangan : N0T1 $=$ Kombinasi tanpa pemupukan nitrogen dan olah tanah intensif, N0T2 $=$ Kombinasi tanpa pemupukan nitrogen dan olah tanah minimum, NOT3= Kombinasi tanpa pemupukan nitrogen dan tanpa olah tanah, $\mathrm{N} 2 \mathrm{~T} 1=$ Kombinasi pemupukan nitrogen $200 \mathrm{~kg} \mathrm{~N} \mathrm{ha}^{-1}$ dan olah tanah intensif, N2T2= Kombinasi pemupukan nitrogen $200 \mathrm{~kg} \mathrm{~N} \mathrm{ha}^{-1}$ dan olah tanah minimum, N2T3= Kombinasi pemupukan nitrogen $200 \mathrm{~kg} \mathrm{~N} \mathrm{ha}^{-1}$ dan tanpa olah tanah.

dikendalikan secara manual dan kimiawi, sisa-sisa tanaman pada musim tanam sebelumnya digunakan untuk menutupi permukaan tanah, agar menjaga kelembaban dan aerasi yang baik, serta menyimpan air untuk bebutuhan tanaman (Utomo, 1989).

Pengolahan tanah konservasi relatif menguntungkan untuk pertanian jangka panjang, di antaranya memelihara atau memperbaiki struktur tanah dan kandungan bahan organik tanah, meningkatkan ketersediaan air, memperbaiki infiltrasi dan mengurangi kerusakan lingkungan, serta dapat meningkatkan hasil
tanaman(Arsyad, 2010).

Pada penelitian ini, perlakuan pemupukan nitrogen memberikan pengaruh yang nyata terhadap kandungan karbon organik tanah. Tetapi pemupukan nitrogen dengan dosis $200 \mathrm{~kg} \mathrm{ha}^{-1}$ memiliki kandungan bahan organik lebih rendah dibandingkan dengan tanpa pemupukan nitrogen. Hal ini diduga akibat pemupukan nitrogen dengan dosis $200 \mathrm{~kg} \mathrm{ha}^{-1}$ jangka panjang memacu proses dekomposisi bahan organik tanah sehingga semakin lama karbon yang tersisa semakin sedikit dibandingkan dengan tanpa pemupukan nitrogen. 


\section{Berat Volume Tanah, Porositas Tanah dan Persen}

\section{Volume Pori Total}

Faktor lain yang mempengaruhi permeabilitas tanah adalah berat volume tanah, porositas tanah, dan volume pori total. Tabel 4 menunjukkan nilai rata-rata berat volume tanah, berat jenis tanah, porositas tanah dan persen volume pori total.

Perlakuan sistem olah tanah dan pemupukan nitrogen tidak berpengaruh nyata terhadap berat volume tanah, porositas tanah, dan volume pori total. Hal ini diduga karena mulsa yang berasal dari gulma dan residu tanaman yang diberikan terlalu sedikit hanya 6-8 ton ha $\mathrm{a}^{-1}$ (Utomo, 2012). Padahal menurut Brown dan Dicky(1970) dalam Khair (2017). Pemberian bahan organik dari tanaman penutup tanah (gulma) dan sisa-sisa tanaman yang dibenamkan ke dalam tanah sebelum tanam dapat meningkatkan porositas tanah. Selain itu, pengolahan tanah juga dapat menurunkan berat volume tanah. Untuk menurunkan kerapatan isi tanah, meningkatkan permeabilitas, porositas, dan ruang pori total diperlukan mulsa sisa tanaman lebih dari 11 ton ha ${ }^{-1}$. Seperti diketahui, olah tanah konservasi pada tahun ke-30 diolah kembali, sehingga menurunkan berat volume tanah dan meningkatkan porositas tanah pada olah tanah konservasi.

\section{KESIMPULAN}

Simpulan dari hasil penelitian ini yaitu kelas permeabilitas tanah tidak dipengaruhi oleh sistem olah tanah dan pemupukan nitrogen, serta tidak terjadi interaksi antara kedua perlakuan, dan kelas permeabilitas tanah pada semua kombinasi perlakuan masuk ke dalam kelas sedang.

\section{DAFTAR PUSTAKA}

Afandi. 2019. Metode Analisis Fisika Tanah. Anugrah Utama Raharja. Bandar Lampung.

Ardiansyah, R., I. S. Banuwa, dan M. Utomo. 2015. Pengaruh sistem olah tanah dan residu pemupukan nitrogen jangka panjang terhadap struktur tanah, bobot isi, ruang pori total, dan kekerasan tanah pada pertanaman kacang hijau (Vignia radiata L.). Jurnal Agrotek Tropika. (3): 283-289.

Arsyad, S. 2010. Konservasi Tanah dan Air. Edisi Kedua,IPB. Press. Bogor.

Kartasapoetra, A.G, dan N. N. Sutedjo. 2010. Teknologi Konservasi Tanah dan Air. Rineka Cipta. Jakarta. Hal 212.

Khair, R. K. 2017. Pengaruh olah tanah dan pemupukan nitrogen jangka panjang terhadap bobot isi, ruang pori total, kekerasan tanah, dan produksi tanaman jagung (Zea mays L.) di lahan Polinela Bandar Lampung, Lampung. Skripsi. Fakultas Pertanian. Universitas Lampung.

Niswati, A., M. Utomo, dan Nugroho, S.G. 1994. Dampak Mikrobiologi Tanah Penerapan Teknik Tanpa Olah Tanah dengan Herbisida Amino Glifosfat Secara Terusmenerus pada Lahan Kering di Lampung. Laporan Penelitian DP3M. Unila. Lampung.

Rachman, A. A. Dariah, dan E. Husen. 2004.Konservasi Tanah Pada Lahan Kering Berlereng. Pusat Penelitian dan Pengembangan Tanah Agroklimat. Badan Litbang Pertanian. Departemen Pertanian. 204hlm.

Rohmat, A. 2009. Tipikal Kuantitas Infiltrasi Menurut Karakteristik Lahan. Erlangga. Jakarta. 
Subandi, 2003. Peranan Benih Berkualitas Varietas Unggul Dalam Meningkatkan Produksi Jagung. Makalah Disampaikan pada acara "Sosialisasi Produksi Benih Jagung Unggul Nasional dan Distribusinya" Balitsereal-Maros: 15-21 Desember 2003.
Utomo, M. 2012. Tanpa Olah Tanah Teknologi Pengelolaan Pertanian Lahan Kering. Lembaga Penelitian Universitas Lampung. Bandar Lampung. 